\title{
EVENTS
}

\section{Upcoming International Events}

Published online: 18 April 2007

(C) Springer-Verlag 2007

\section{September 3-5, 2007, Istanbul, Turkey}

13th European Meeting of Environmental \& Engineering Geophysics.

URL: http://www.eage.nl/events/index.php?

\section{September 3-7, 2007, Tromsø, Norway}

The Arctic Conference Days in the International Polar Year 2007-2008 will consist of three separate, but tightly related conferences: (1) ICAM V, the Fifth International Conference on Arctic Margins on September 3-5 provides a forum for the exchange of information and presentation of current Arctic research; (2) AGReE II, the Second Conference on Arctic Geology, Resources and Environment on September 6-7; and (3) SEST, the Conference on "Shelf Edge and Shoreline Trajectories, a Dynamic Approach to Stratigraphic Analysis" on September 3-4. The Conference Days are hosted by the Geological Society of Norway (NGF) in cooperation with the European Association of Geoscientists and Engineers (EAGE).

URL: http://www.icamv.org

\section{September 5-7, 2007, Coimbra, Portugal}

6th International Conference on Ecosystems and Sustainable Development (ECOSUD 2007) organised by Wessex Institute of Technology, UK, the University of Coimbra, Portugal and the University of Siena, Italy focuses on those areas that will most benefit from the application of scientific methods for sustainable development, and will include mathematical models and eco-informatics, evolutionary thermodynamics and biodiversity, structures in ecosystems modelling and landscapes. Invited presentations include: merging environ theory; The UN Global Compact: moving toward sustainable development by adopting a new paradigm; Thermodynamic characteristics for ecosystems with porous nonlinear interactions; On the complexity of ecological sustainability; Economic/fiscal benefits of sustainable reinvestment versus dispersed development of sprawl; Simplicity versus complexity in mathematical ecology. Would we live in Volterra's world? Complexity of planning process; Community analysis and water quality assessment across different levels of pollution in streams; A novel soil conservation technology; Ecological utility analysis: Emergence of positive interactions between organisms in ecosystems; Emergence of novelties: a thermodynamic approach to ecosystems. Contact: Wessex Institute of Technology, Ashurst Lodge, Ashurst, Southampton, SO40 7AA, UK.

Tel: $+44(0) 238-029-3223$

E-mail: enquiries@wessex.ac.uk

URL: http://www.wessex.ac.uk

\section{September 5-7, 2007, Cos Island, Greece}

International Conference on Environmental Science and Technology (CEST2007) organized by the Global Network for Environmental Science and Technology and the University of the Aegean. Contact: CEST2007 Secretariat, University of the Aegean, 30, Voulgaroktonou str., GR 114 72 Athens, Greece.

Tel: +30 2106492450

Fax: +30 2106492499

E-mail: cest2007@gnest.org

URL: http://www.gnest.org/cest 


\section{September 9-13, 2007, Copenhagen, Denmark}

International Conference on Calibration and Reliability in Groundwater Modelling-Modelcare2007.

URL: http://www.polytec.dk/mdelcare2007/

\section{September 9-14, 2007, Torquay, Devon, UK}

23rd International Organic Geochemistry Meeting (IMOG07) is organized by the European Association of Organic Geochemistry (EAOG). Contact: Sally Cornford, IGI Ltd, Hallsannery, Bideford, Devon EX39 5HE, UK.

Tel: +44(0)1237-471749

E-mail: sal@igiltd.com

URL: http://www.eaog.org/meetings/meetings.html

\section{September 10-12, 2007, London, UK}

Bicentennial Conference on Earth Sciences in the Service of Society: "the next 200 years" is organized by the Geological Society of London. Contact: The Geological Society, Burlington House, Piccadilly, London W1J 0BG UK.

Tel: +44-20-7434-9944

E-mail: enquiries@geolsoc.org.uk

\section{September 10-13, 2007, Athens, Greece}

11th ACUUS International Conference Underground Space: Expanding the Frontiers. The Associated Research Centers for Urban Underground Space (ACUUS) conference aims not only at strengthening and promoting the scientific knowledge but also at bringing closer engineers, architects, policy planners and decision makers, in a pursue to bridge the gap between them and adopt common policies that will allow the faster adaptation of underground development. The Conference will focus on the following themes: Underground space utilization; Environmental aspects of underground development; Risk assessment and rock engineering; Underground projects; Economics of underground development; Legislation and proprietary rights of underground space; Aesthetics and architectural planning of underground environments; Public acceptance of urban underground development; Visualization of underground environments; and Future challenges in underground development.

E-mail: contact@acuus2007.ntua.gr

URL: http://www.acuus2007.ntua.gr

\section{September 16-20, 2007, Tallinn, Estonia}

15th Meeting of the Association of European Geological Societies (MAEGS-15) entitled "Georesources and public policy: research, management, environment". The Meeting will not be geographically restricted to Baltic Region or Europe. Contact: Conference secretary, Saima Peeterman

E-mail: maegs15@maegs15.org

URL: http://www.maegs15.org/

\section{September 17-21, 2007, Lisbon, Portugal}

Groundwater and Ecosystems 35th Congress of IAH. Topics include: groundwater/surface water interactions and their importance for the sustainability of river, spring base flow systems and wetlands; estuarine and near shore marine systems; cave and aquifer ecosystems; groundwater quantity, baseline quantity and main threatening processes in dependant ecosystems; sustainability of transboundary ecosystems and aquifers; and impact of climate and global changes on groundwater dependent ecosystems. Workshops, technical sessions, and excursions are planned. Contact: XXXV IAH Congress Secretariat, Departamento de Geociências, Universidade de Aveiro, Campus Universitário de Santiago, 3810-193, Aveiro, Portugal.

E-mail: iah2007@gmail.com

URL: http://www.geo.ua.pt/aih-gp/iah2007

\section{September 18-21, 2007, Cracow and Krynica, Poland}

V International Conference Mining Techniques TUR 2007 focuses on the following issues: Techniques of hard rocks and coal excavation; Mining of hard rocks and coal: protection of natural environment and clean mining technologies; Development of mining machinery construction; Mining lands reclamation and problems of mines removal.

URL: http://www.home.agh.edu.pl/ kmg/TUR/EN/index. html

\section{September 24-26, 2007, Washington, DC, USA}

Conference on the Science and Education of Land Use: A transatlantic, multidisciplinary and comparative approach is organized by National Association of State Universities and Land-Grant Colleges (NASULGC) and the Interuniversity Consortium for Agricultural and Related Sciences in Europe (ICA). It explores the causes and consequences of current land use trends and dynamics related to society, 
economy and environment. It will identify the major drivers of land use and address the questions of what will happen if we keep doing what we are doing now, and what alternative measures could strengthen the sustainable use of natural resources in rural and suburban areas. Contact in the USA: Stephan J. Goetz, International Committee Chair, E-mail: sgoetz@psu.edu, Contact in Europe: Dr. Floor Brouwer, International Committee Vice-Chair

E-mail: Floor.Brouwer@wur.nl

URL: http://www.nercrd.psu.edu/TALUC/

\section{September 24-26, 2007, Szczecin, Poland}

"GeoPomerania 2007-Geology cross-bordering the Western and Eastern European Platform' organized by the Geological Society of Poland and the German Society for Geoscience (DGG). Topics include: Southern Permian basin/Central European basin system; Regional geology, Structures and hydrocarbon potential; Regional stratigraphy; Global Devonian, Carboniferous and Permian correlations; Cross-boundary groundwater management; Coastal dynamics; Geopotentials and resources; Climate change; Environmental geology; Geoarchaeology; Geoheritage, geotourism and geoparks. Field trips are planned. Contact: Conference secretary, Ms. Ogarit Uhlmann, F\&U confirm, Permoserstr. 15, D-04318 Leipzig, Germany.

Tel: +49-341-235-2264

E-mail: geopomerania@fu-confirm.de

URL: http://www.geopomerania2007.org/

\section{October 2-5, 2007, Bremen, Germany}

International Conference "The Oceans in the Earth System" and 97th Annual Meeting of the Geologische Vereinigung e.V. Session themes: Biogeochemistry; Paleoclimate; Coastal zone and shelf processes; Geohazards; Methods; and Outreach. The conference includes three workshops: Marine proxy research; How to constrain oxygen 18-based water-mass reconstructions; and African response to global change. Short courses include: Seismoacoustic imaging and geologic interpretation; Getting data in and out of WDC-MARE; New technologies (vehicles and platforms); and Geology of marine gas hydrates. Contact: CV International Conference 2007, c/o Gerold Wefer, Geowissenschaften, Universität Bremen, MARUM, Loebener Strasse, 28359 Bremen, Germany.

Tel: +49(0)421-218-65521

E-mail: GV-2007@marum.de

URL: http://www.g-v.de

\section{October 7-11, 2007, Traverse City, MI, USA}

44th Meeting of the American Institute of Professional Geologists announces the theme "Geology: The Foundation for the Environment and Resources". The 2007 meeting not only incorporates our goal of highlighting the role of geology in defining, protecting, and sustaining our environment and its resources, but also offers a forum to provide opportunities for reporting on regional geologic studies pertaining to a variety of topics. Contact: Adam Heft, 3125 Sovereign Dr. Suite D, Lansing, MI 48911, USA.

Tel: +1-517-887-1100

E-mail: hefta@fitzhenne.com

URL: http://www.mi.aipg.org/2007\%20Ann\%20Mtg/ 2007Conference.html

\section{October 8-10, 2007, Athens, Greece}

8th International Hydrogeological Congress of Greece organised by the Hellenic Committee of Hydrogeology in collaboration with the Cyprus Association of Geologists and Mining Engineers. Contact:

E-mail: hydrogeology@aua.gr

URL: http://www.iah-hellas.geol.uoa.gr

\section{October 28-31, 2007, Denver, CO, USA}

2007 Geological Society of America Annual Meeting: Earth Sciences for Society will be tying the annual meeting program to the themes of the International Year of Planet Earth.

\section{October 28-November 2, 2007, Phoenix, AZ, USA}

6th Biennial International Symposium on Managed Aquifer Recharge (ISMAR6) is organized by the Arizona Hydrological Society (AHS) in partnership with IAH, ASCE/ EWRI, and UNESCO. Workshops, sightseeing tours, and field trips to innovative aquifer recharge projects are planned. Contact: Doug Bartlett, Symposium Co-Chair.

E-mail: info@ismar6.org

URL: http://www.ismar2007.org

\section{November 6-9, 2007, Braunschweig, Germany}

International Congress on Radioactive Waste Disposal in Geological Formations.

URL: http://www.reposafe.de 


\section{November 11-16, 2007, Taupo, New Zealand}

18th International Symposium on Environmental Biogeochemistry "Environmental Biogeochemistry at the Extremes" is organized by the University of Auckland. It will focus on biogeochemical processes occurring under extreme environmental conditions, but not to the exclusion of processes in the more "normal" environments, which help define these extremes. Provisional session themes are: Marine, Subsurface, Freshwater, Desert, Frozen, Geothermal \& Volcanic, Extraterrestrial, and Terrestrial. Contact: Jenny Webster-Brown (Chair), University of Auckland, NZ.

E-mail: ISEB18@auckland.ac.nz

URL: http://www.isebiogeochemistry.com

\section{November 12-16, 2007, Noordwijk, The Netherlands}

The European Mars Science and Exploration Conference (EMSEC).

URL: http://www.rssd.esa.int/mars07

\section{November 19-22, 2007, Rio de Janeiro, Brazil}

10th International Congress of the Brazilian Geophysical Society (Sociedade Brasileira de Geofísica, SBGf) is called Rio2007 with the theme "Unveiling the Earth". The exhibition EXPOGEF 2007 runs parallel to this event. It is sponsored by the Society of Exploration Geophysics (SEG), the European Association of Geoscientists and Engineers (EAGE) and the Union Latin American Geophysicists (ULG). The Congress will focus on major advances in exploration and exploitation of oil and gas in Brazilian sedimentary basins, especially in deep and ultra deep waters of the prolific basins of the east continental margin. A technical program covers a wide range of geophysical topics pertaining to the oil industry, but also focusing on mining, environmental, solid earth and space geophysics. Contact: Brazilian Geophysical Society, Avenida Rio Branco 156, Rooms 2509-2510, Rio de Janeiro-RJ 20043-900, Brazil.

Tel: + 55-21-2533-0064

E-mail: rio2007@sbgf.org.br

URL: http://www.congresso.sbgf.org.br

\section{November 19-23, 2007, Shimabara, Japan}

5th International Conference on Cities on Volcanoes aims to bring together volcanologists, city planners, social scientists, disaster managers, the medical community, and mass media to exchange and understand their experiences and knowledge in order to evaluate and improve prevention and mitigation measures, land use planning, emergency management, all required to successfully confront volcanic crises in densely populated areas and to recovery from the devastation. Contact: Cities on Volcanoes 5 Secretariat Office, 1-1 Heisei-machi, Shimabara city, Nagasaki 8550879 Japan.

E-mail: convention@citiesonvolcanoes5.com

URL: http://www.citiesonvolcanoes5.com/

\section{December 1-7, 2007, Fremantle, Australia}

5th International IAHS Groundwater Quality Conference 2007 "Securing Groundwater Quality in Urban and Industrial Environments". An extensive list of topics and themes can be found at website. Contact: Wendy Whitford, CSIRO, Bag 10, Clayton South VIC Australia 3169.

Tel: +011-61-8-9333-6273

E-mail: Wendy.Whitford@csiro.au

URL: http://www.clw.csiro.au/conferences/GQ07

\section{December 8-10, 2007, Bangkok, Thailand}

SWEMP 2007: 9th International Symposium on Environmental Issues and Waste Management in Energy and Mineral Production. Conference themes: Environmental impacts of coal-fired power projects; Emission control in thermal power plants; Greenhouse gas abatement technologies; Sustainable development for mineral and energy industries; Remediation of contaminated groundwater, bioremediation of contaminated soil and groundwater; Environmental impacts: national reports; Environmental issues in surface and underground mining; Occupational health and safety and rehabilitation of mineworkers; Control of effluents from mineral processing, Metallurgical and chemical plants; Emerging technologies for environmental protection; Mine site closure and rehabilitation; Computer modeling and applications; Recovery of useful components from industrial waste; Geographical information systems and remote sensing; Reliability of waste containment structures, Tailings disposal; New and more efficient use of energy; and Managing mine waste and mine water at the river basin scale. Contact: Dr. Raj K. Singhal, University of Laval, PO Box 68002, Crowfoot Postal Outlet, 28 Crowfoot Terrace NW, Calgary, Alberta, T3G 1Y0 Canada.

Fax: +403-241-9460

E-mail: singhal@shaw.ca or

URL: http://www.mpes-cami-swemp.com 


\section{8, Carlsbad, Czech Republic}

10th International Mine Water Congress organized by Ostrava University (Czech Republic), the University of Silesia (Poland) and the International Mine Water Association. Contact: IMWA International Mine Water Association, Dr. Christian Wolkersdorfer, General Secretary, Vor dem Meißner Tor 10, 09599 Freiberg, Germany.

URL: http://www.imwa.info

\section{8, Hong Kong, People's Republic of China}

9th International Symposium on Environmental Geotechnology and Global Sustainable Development is organized within the International Society for Environmental Geotechnology (Charlotte USA) conference series. Contact: Dr. Albert Yeung. Department of Civil Engineering, University of Hong Kong, P. R. of China.

E-mail: eyeungat@hkucc.khu.hk

\section{March 31-April 3, 2008, Adelaide, Australia}

2nd International Salinity Forum: 'Salinity, Water and Society-Global issues, local action' aims to deal with a broad range of salinity issues including groundwater and acquifer salinity, irrigation, dryland/rangeland and salt water intrusion. Contact: Helen Nealer.

Tel: +61-2-6281-6624

E-mail: conference@conlog.com.au

URL: http://www.internationalsalinityforum.org

\section{May 30-June 2, 2008, Nanjing, China}

2nd International Conference on Geotechnical Engineering for Disaster Mitigation and Rehabilitation (GEDMAR08) organized by Hohai University, China; Chinese Institution of Soil Mechanics and Geotechnical Engineering, CCES; and Chinese Society of Environmental Geotechnics, CSRME. Main conference theme: Enhancing disaster mitigation and rehabilitation capabilities through research and development. Contact: Dr. A. Deng, Dr. T. Zhang, GeoHohai, Hohai University, 1 Xikang Road, Nanjing 210098, China.

Tel: +86258378 7917

Fax: +86 2583713073

E-mail: GEDMAR08@hhu.edu.cn

URL: http://www.GeoHohai.com/GEDMAR08
June 25-28, 2008, Kampala, Uganda

Groundwater and Climate in Africa-an international conference is organized by the Directorate of Water Development (Uganda) and supported by UNESCO/IHP, IAHS, IHDP/START. It brings together water and climate scientists from research/academic institutions, government, the private sector, international agencies, donors and consortia in order to share knowledge and expertise, and thereby improve current understanding of the impact of climate variability and change on groundwater resources in Africa. Topics include: Groundwater-based livelihoods; Groundwater-fed ecosystems; Monitoring and modelling groundwater use and replenishment; Estimation of groundwater resources and demand; Groundwater management. Contact: Richard Taylor,

E-mail: info@gwclim.org

URL: http://www.gwclim.org/test.php

\section{June 29-July 3, 2008, Fairbanks, AK, USA}

9th International Conference on Permafrost (NICOP) is organized during the International Polar Year in 2008. A list of conference themes can be found at the website. Contact: Doug Kane, Water \& Environmental Research Center, Institute of Northern Engineering, U. of Alaska Fairbanks, PO Box 755860, Fairbanks, AK 99775-5860 USA.

Tel: +1-907-474-7808

E-mail: contact@nicop.org

URL: http://www.nicop.org

\section{July 13-18, 2008, Vancouver, BC, Canada}

Goldschmidt Conference 2008. Contact: Organizing Committee Goldschmidt 2008, Dominique Weis, The University of British Columbia, Vancouver, Canada.

Tel: +1-604-822-1697

E-mail: dweis@eos.ubc.ca

\section{August 5-14, 2008, Oslo, Norway}

33rd International Geological Congress (IGC 33). "Earth System Science: Foundation for Sustainable Development" is a collaboration with the International Union of Geological Sciences (IUGS) and many other international and national organisations, the National IUGS Committees in the five Nordic Countries. It will span the whole field of Earth science, binding together classical geology with 
geophysics, geochemistry, and the biogeosciences. Main themes include: human influence on the Earth system; managing a changing planet, and geological resources for the 21st Century and their environmental challenge. Special symposia focus on two main subjects: Norden (the Nordic countries) and the Arctic and Bipolar relationships. A wide range of scientific publications are planned. See website for planned excursions. Contact: 33 rd IGC, c/o Congress-Conference AS, P.O. Box 2694 Solli, Thomas Heftyesgate. 2, NO-0204 Oslo, Norway.

Tel: +47-2256-1930

E-mail: SciComIGC@geo.uu.se

URL: http://www.33igc.org

\section{September 1-4, 2008, Montpellier, France}

XIIIth World Water Congress "Global Changes and Water Resources-confronting the expanding and diversifying pressures" is organized by International Water Resources Association (IWRA) and others. It aims to enhance the world's knowledge and raise global consciousness of the impact of global changes on water resources. Contact: XIIIth World Water Congress, Domaine de Lavalette, 859 rue JeanFrançois, Breton, 34093 Montpellier CEDEX 5-France.

Tel: +33(0)4-67-612948

E-mail:wwc2008@msem.univ-montp2.fr

URL: http://wwc2008.msem.univ-montp2.fr

\section{October 1-6, 2008, Goa, India}

12th International Association for Computer Methods and Advances in Geomechanics (IACMAG) conference. Details of past conferences are available at http://www. iacmag.org/index 1.html. Contact: Dr. D. N. Singh, Department of Civil Engineering Geotechnical Engineering Division Indian Institute of Technology, Bombay Powai, Mumbai-400 076, India.

Fax: +91-22-2576 7302

E-mail:dns@civil.iitb.ac.in

URL: http://www.12iacmag.com

\section{October 8-10, 2008, Athens, Greece}

8th International Hydrogeological Congress of Greece organised by the Hellenic Committee of Hydrogeology in collaboration with the Cyprus Association of Geologists and Mining Engineers. Contact: Dr. G. Migiros, P.O.B. 27602, 10020 Votanikos, Greece.
Tel: +30-210-5294157

E-mail: hydrogeology@aua.gr

URL: http://www.iah-hellas.geol.uoa.gr

\section{October 26-November 1 2008, Toyama, Japan}

The 35th Congress of IAH, "Integrating Groundwater Science and Human Well-being" hosted by the Japanese Chapter of the International Association of Hydrogeologists, will address issues of human well-being that depend upon the study and understanding groundwater science. Topics include: Groundwater and natural/man-induced disasters; Groundwater under climate change/climate change impacts on groundwater resources; Response of groundwater systems to climate change, Impact of sea level rise on groundwater systems, and Knowledge from paleohydrology; Groundwater development and management for sustainability and security; Roles of groundwater in ecosystems; Scientific understanding and communication on groundwater; and General contribution in hydrogeology. Contact: Japanese Association of Environmental Hydrology. 3-11-19 Matsunami, Chuo-ku, Chiba City, Chiba 260-0044, Japan.

E-mail: IAH2008@envr.tsukuba.ac.jp

\section{August 5-15, 2012, Brisbane, Australia 份出}

34th International Geological Congress (IGC34). Contact: Dr. Ian Lambert, Geoscience Australia.

Tel: +61 262499556

Fax: +61 262499983

E-mail: Ian.Lambert@ga.gov.au

URL: http://www.ga.gov.au/igc2012

\section{Publishing International Events}

Each month the events section of Environmental Geology publishes a broad array of relevant international geoscience meetings, conferences, workshops and short courses that focus on environmental geology themes. Scientists, professionals, and conference organizers may easily announce their planned events free of charge by contacting our assistant editor:

Anne Marie de Grosbois degrosbois@blue-cable.de 